\title{
2. HIGH-TEMPERATURE DUCTILE DEFORMATION OF SITE 920 PERIDOTITES ${ }^{1}$
}

\author{
Georges Ceuleneer ${ }^{2}$ and Mathilde Cannat ${ }^{3}$
}

\begin{abstract}
The high-temperature textures of the serpentinized harzburgites drilled during Ocean Drilling Program Leg 153 range from coarse-grained equigranular to mylonitic. Coarse-grained equigranular texture is fully preserved in about $5 \%$ of core, and becomes increasingly abundant downhole. It consists of a mosaic of equant olivines and equant to slightly elongate pyroxenes, ranging in size from a few $\mathrm{mm}$ to more than $1 \mathrm{~cm}$. Olivine presents a moderately developed lattice fabric resulting from crystalplastic flow under conditions of very high temperature $\left(>1200^{\circ} \mathrm{C}\right)$ and low stress $(<1 \mathrm{MPa})$. The flow plane associated with this fabric is subhorizontal (average dip of $10^{\circ}$ ). The flow line is preferentially oriented west-northwest-east-southeast, at a low angle to the spreading direction. In most samples, the coarse olivine crystals are partly ( $70 \%$ of the studied samples) to totally ( $25 \%$ of the samples) replaced by a medium-grained (around $1 \mathrm{~mm}$ ) mosaic of olivine crystals displaying well-developed euhedral shapes. Grain-size reduction of pyroxene crystals is locally well developed. We interpret this texture in terms of static recovery and recrystallization that postdated the formation of the lattice fabric and that is synchronous with, or slightly postdates, a melt percolation event evidenced by trails of strain-free poikilitic clinopyroxenes enclosing medium-grained olivine crystals. In about $30 \%$ of the samples, virtually restricted to the upper half of the hole, the coarse- and medium-grained textures are slightly overprinted by a higher-stress (10-100 MPa) and lower-temperature (around $1000^{\circ} \mathrm{C}$ ) deformation texture, as shown by the development of a fine-grained $(0.1-0.3 \mathrm{~mm})$ matrix and of closely spaced subgrain boundaries in olivine and pyroxene (porphyroclastic textures). Low total strain is associated with this lower-temperature deformation, as evidenced by the limited development of the fine-grained matrix (typically $10 \%-20 \%$ matrix only). Mylonites ( $>90 \%$ matrix) are scarce $(<1 \%$ of the core recovery), and are restricted to millimeter- to centimeter-thick shear zones that, in all cases, are spatially related to gabbroic veins.
\end{abstract}

\section{INTRODUCTION}

Exposures of serpentinized peridotites on the median valley walls of mid-ocean ridges and along transform faults scarps are the only windows to the present-day upper mantle. They provide a unique opportunity to study deformation, partial melting, and melt migration processes in the mantle below active oceanic spreading centers (e.g., Dick, 1989; Cannat et al., 1990a,b; Girardeau and Francheteau, 1993; Cannat and Casey, 1995). Serpentinized peridotites from the Mid-Atlantic Ridge at the Kane Fracture Zone (MARK) area are exposed in a 30-km-long stretch along the western median valley wall (Fig. 1; Karson et al., 1987; Mével et al., 1991). Serpentinized peridotites have also been dredged (Cannat et al., 1995) and drilled (Shipboard Scientific Party, 1979) at off-axis locations in the North American Plate, as far as anomaly 5 (7-m.y-old lithosphere). The emplacement of these rocks at shallow levels in the oceanic crust is thought to have resulted from large-offset faulting of the axial lithosphere, in the context of magma starved spreading (Karson, 1990; Cannat, 1993). During Ocean Drilling Program (ODP) Leg 153, Holes 920B and 920D were successfully drilled into the peridotites along the western wall of the Mid-Atlantic Ridge, about $35 \mathrm{~km}$ south of its intersection with the Kane Fracture Zone (Figs. 1A, 1B). Penetration in the deepest hole (Hole 920D) reached $200.8 \mathrm{~m}$ and had a cumulate recovery of 47.4\% (Fig. 1C). This study describes the high-temperature deformation textures in these samples, and provides constraints on the rheology of the upper mantle beneath slow-spreading ocean ridges.

Deformation structures observed in peridotites from Site 920 comprise two broad categories: (1) high-temperature, crystal-plastic

'Karson, J.A., Cannat, M., Miller, D.J., and Elthon, D. (Eds.), 1997. Proc. ODP, Sci. Results, 153: College Station, TX (Ocean Drilling Program).

${ }^{2}$ Observatoire Midi-Pyrénées, CNRS-UPR 234, 14 av. E. Belin, 31400 Toulouse, France.ceulener@pontos.cnes.fr

'Laboratoire de Pétrologie-URA CNRS 736, Université Pierre et Marie Curie, 4 place Jussieu, 75252 Paris cedex 05, France. structures and (2) structures that developed at lower temperatures, in the stability field of serpentine ( $<$ about $600^{\circ} \mathrm{C}$ ). Most of the low-temperature structures are anastomosing serpentinized faults and fractures. Evidence for shearing postdating serpentinization is rare in the cores of Holes 920B and 920D, although it might be the result of selective recovery. The static overprint related to serpentinization has left the higher-temperature deformation structures preserved in the recovered rocks.

Here we focus on the crystal-plastic fabric and on the geometry of the related deformation based on mesoscopic observations, on petrographic study (about 150 thin sections regularly distributed downhole; spacing ranging from 1 to $2 \mathrm{~m}$ ), and on U-stage petrofabric data collected from 20 samples. Mesoscopic observations were performed essentially on board and included measurements of the foliation dip and a qualitative estimate of the finite strain, as deduced from orthopyroxene shape fabric. The petrographic study was performed to characterize the texture of the peridotites and to measure olivine grain sizes systematically. U-stage measurements were preferentially performed on specimens for which the paleomagnetic properties were measured (Hurst et al., this volume). Thus, using magnetic declination corrections, it was possible to reorient deformation structures relative to north. Because Hole 920B appeared very similar in terms of lithology and structure to the upper half of Hole 920D, we focused our sampling and the laboratory work on samples from this last hole.

\section{TEXTURES AND LATTICE FABRICS}

Mesoscopically, harzburgites of Site 920 can be described as porphyroclastic rocks. The term porphyroclastic refers to a bimodal grain-size distribution in a deformed rock (Boullier and Nicolas, 1973; Mercier and Nicolas, 1975; Nicolas et al., 1980; Mercier, 1985). Site 920 harzburgites consist of coarse (several millimeters to a few centimeters), variably elongated pale elements, interpreted as deformed orthopyroxene porphyroclasts, embedded in a darker 
A
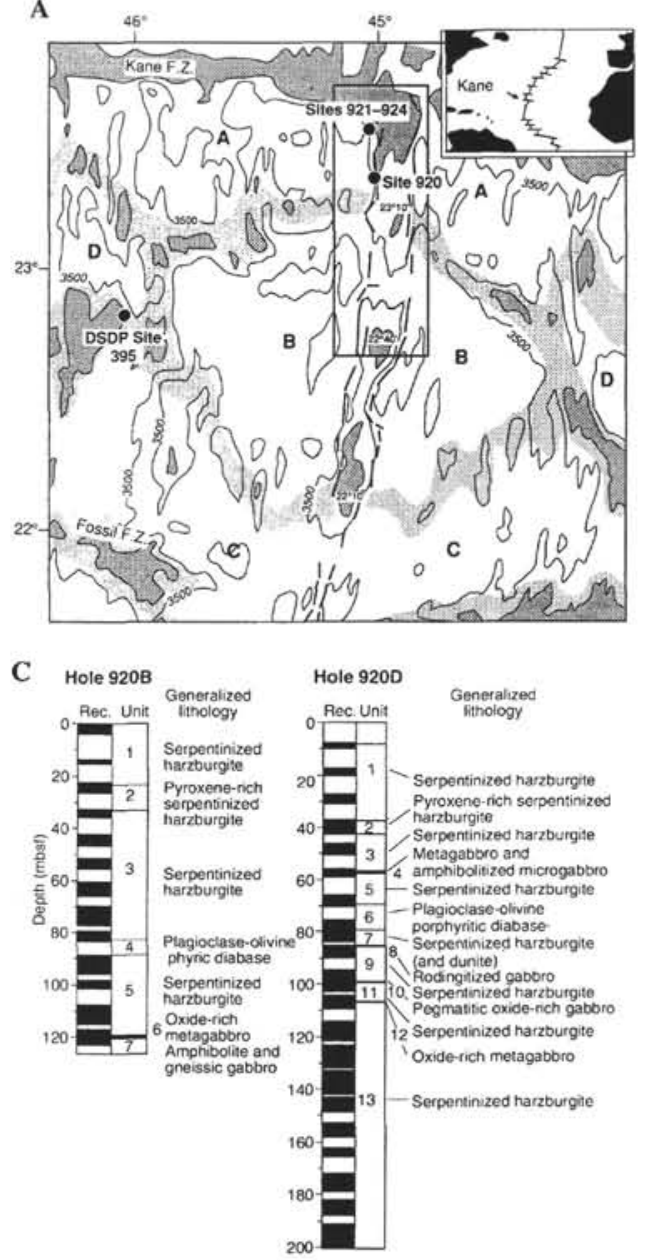

B

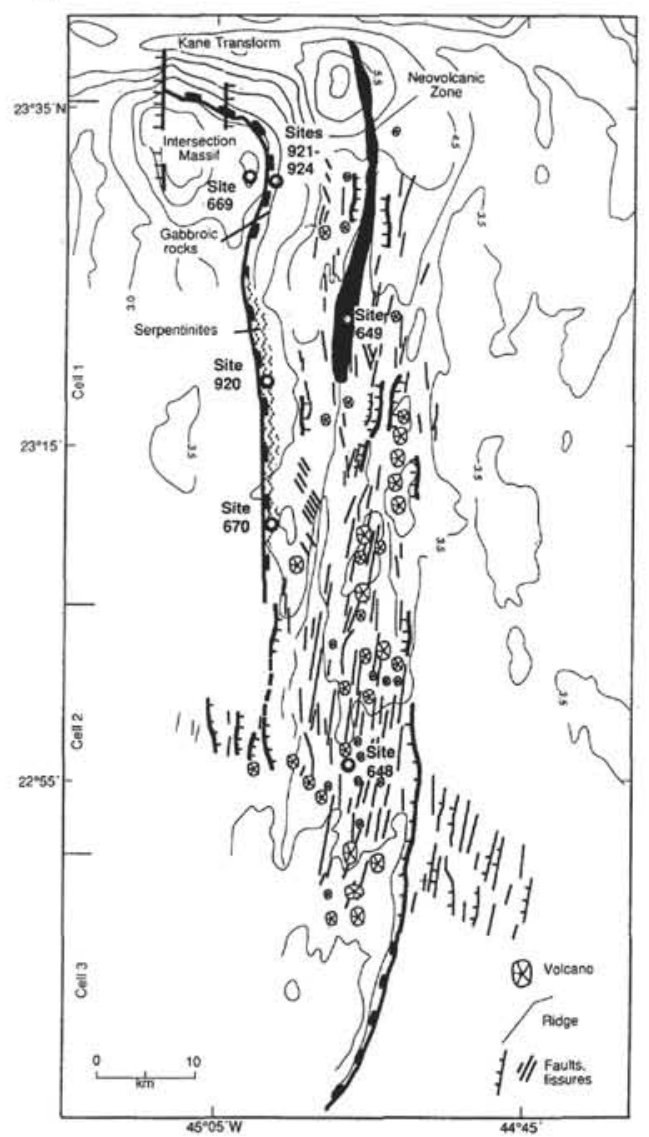

Figure 1. A. Location of Site 920. B. Tectonic sketch of the MARK area around Site 920; area of serpentinized outcrops shown as zigzag lines. C. Core recovery (black) in Holes 920B and 920D, and distribution of lithologic units (Cannat, Karson, Miller, et al., 1995).

groundmass, resembling a finer-grained olivine matrix (Pl. 1, Fig. 1). Thin-section examination shows that this interpretation of the mesoscopic characters of Site 920 peridotites is commonly, but not always, correct and that this seemingly monotonic mesoscopic aspect obscures a rather broad spectrum of textures. First, the pale elements are not, in all cases, orthopyroxene porphyroclasts, but can be polymineralic aggregates of finer-grained olivine, pyroxenes, and spinel that escaped total serpentinization. Second, the dark groundmass can be made of coarse, but heavily serpentinized, olivine crystals whose original size is similar to the orthopyroxene "porphyroclasts."

This section illustrates the microscopic textural spectrum exhibited by Site 920 serpentinized harzburgites. The physical conditions at which the peridotites were deformed can be constrained by measurements of grain size and by description of the morphology and substructure (subgrain boundaries, undulose extinction, etc.) of olivine. This mineral is the most abundant one, and presents a wide variation of these fabric elements, which can easily be interpreted because of extensive experimental calibration (Goetze and Evans, 1979; Darot and Gueguen, 1980; Kirby, 1983; Karato, 1984; Poirier, 1985).

Olivines of Site 920 peridotites are generally present as equant grains; elongate olivine porphyroclasts are restricted to mylonitic textures. Grain size varies from less than $0.03 \mathrm{~mm}$ to more than 10 $\mathrm{mm}$, and grain-size variations are not uniform. Three modes in the grain-size distribution have been distinguished: $\sim 5 \mathrm{~mm}$ (coarse), $\sim 1$ $\mathrm{mm}$ (medium), and $\sim 0.250 \mathrm{~mm}$ (fine). In samples from Hole $920 \mathrm{D}$, medium-sized grains are the most abundant $(\sim 70 \%)$, followed by coarse grains ( $20 \%$ ), whereas fine grains are generally less abundant $(\sim 10 \%)$. Considering the downhole variations (Figs. 2A-2C), it appears that coarse grains become somewhat more abundant only in the lower half of the hole $(\sim 30 \%)$, and are virtually absent from the upper half $(<1 \%)$. The opposite trend is observed for fine grains, the abundance of which decreases down section ( $20 \%$ in the upper half and $\sim 2 \%$ in the lower half of Hole 920D). This downhole variation in grain size is roughly correlated with the spacing of subgrain boundaries: the higher the content of fine grains, the denser the olivine substructure (compare Figs. 2C and 2D). The aspect ratio of orthopyroxene crystals has been used as a qualitative estimate of the finite strain. This probably reflects very small-scale variations in fabric development. The interpretation of this shape fabric is beyond the scope of the present paper. Large aspect ratios tend to be more common in samples showing a high subgrain density and a high content of fine grains (Figs. 2E, 3).

In a single sample, bimodal grain-size distributions (coarse- to medium- or medium- to fine-grained associations) are most common ( $\sim 60 \%$ of the studied samples), then unimodal $(\sim 30 \%)$, and finally trimodal $(\sim 10 \%)$ distributions. Coarse-grained equigranular (i.e., unimodal) textures are not very common $(\sim 5 \%)$, and are restricted to the lower half of Hole 920D (Fig. 2A). In the samples with a coarsegrained equigranular texture, olivine grains show straight to curvilinear boundaries with common $120^{\circ}$ triple junctions (PI. 1, Fig. 2). Oli- 
$\%$ coarse grains

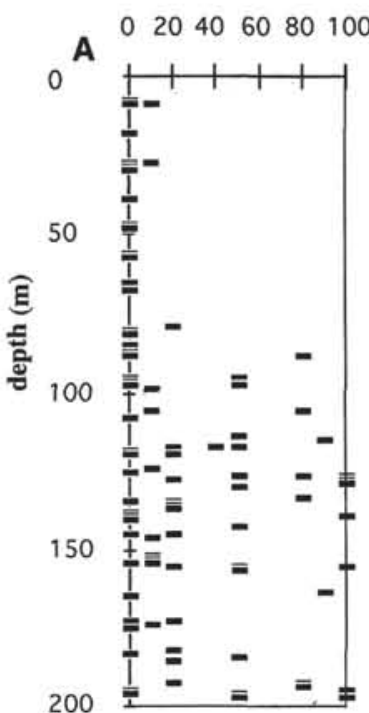

$\%$ medium grains

B
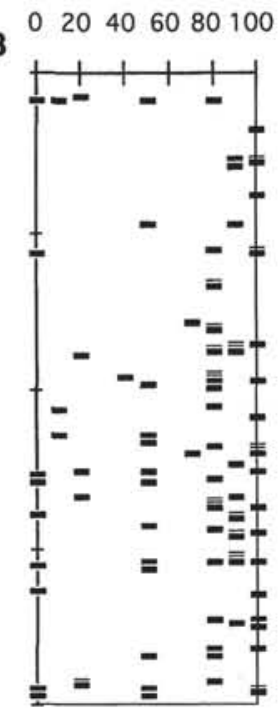

$\%$ fine grains

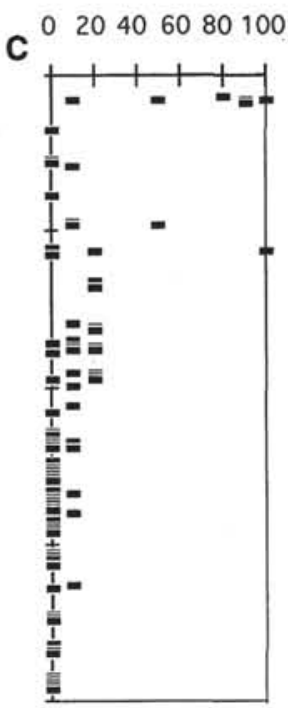

Subgrain boundaries density

Strain

Figure 2. Downhole variations of textural characteristics in Hole 920D peridotites based on a piece-by-piece plot. A. Percentage of coarse-grained (around 5 $\mathrm{mm}$ ) olivine crystals. B. Percentage of medium-grained (around $1 \mathrm{~mm}$ ) olivine crystals. C. Percentage of fine-grained (around $0.3 \mathrm{~mm}$ ) olivine crystals. D. Qualitative estimate of the subgrain boundaries density in olivine crystals $(1=$ low, $2=$ medium, $3=$ high). E. Qualitative estimate of the "finite strain" (i.e., aspect ratio of the pale elements in the cores; $0=$ no elongation, $1=$ weak elongation, $2=$ moderate elongation, $3=$ strong elongation).

A

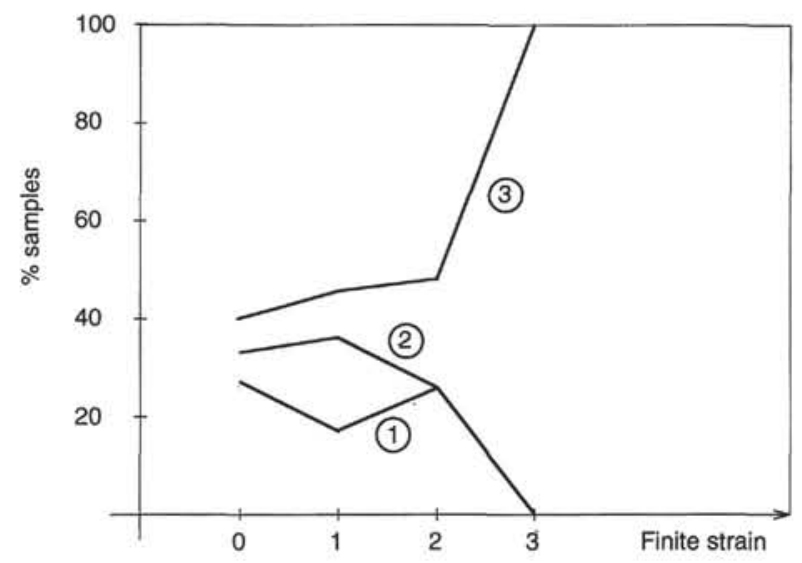

B

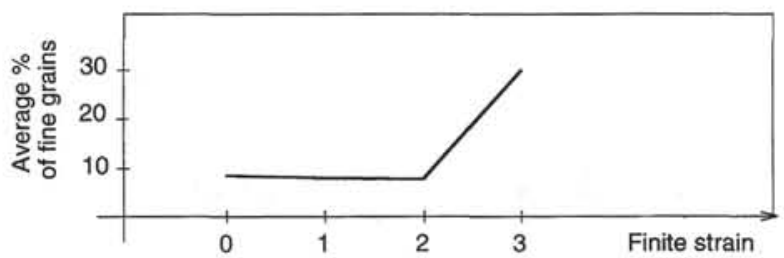

Figure 3. A. Relationship between "finite strain," as defined in Figure 2E, and subgrain boundary density in Hole 920D peridotites; circled numbers refer to the subgrain density as defined in Figure 2D. B. Correlation between finite strain and average percentage of fine grains in Hole 920D peridotites.

vine (Sample 153-920D-15R-3, Piece 3A; Fig. 4A) has a pronounced preferred orientation of [100] axes and a weak preferred orientation of [010] and [001] axes, although a maximum of the [010] axes occurs clearly perpendicular to the foliation plane. The $(010)$ crystallographic plane and the [100] crystallographic direction are the pre- ferred glide plane and direction in olivine at very high (close to solidus) temperature (around $1200^{\circ} \mathrm{C}$ ) (Carter and Avé Lallemant, 1970; Mercier and Nicolas, 1975; Nicolas and Poirier, 1976; Darot and Gueguen, 1980; Mercier, 1985).

Coarse grains more commonly occur as relict grains embedded in a variably developed, medium-grained mosaic (i.e., coarse-medium bimodal distribution) $(\approx 35 \%$ of the observed thin sections). In this instance, coarse-grain boundaries become very irregular (Pl. 1, Fig. 3). These irregular grain boundaries probably result from the growth of medium-grained olivine into coarse-grained olivine (Pl. 1, Fig. 4). The medium-grained olivine crystals commonly have well-developed euhedral shapes and low subgrain-boundary density, contrasting with the coarse grains (Pl. 1, Fig. 6). Preferred orientations of olivine and orthopyroxene in the coarse-medium bimodal texture (all fabrics of Fig. 4A, except thin sections of Samples 153-920D-10R-2, Piece 6, and 15R-3, Piece 3A) are variably developed, but show the same tendencies as the coarse-grained equigranular textures. Olivine [100] axes and orthopyroxene [001] axes present a variably developed preferred orientation. Other axes have a more scattered distribution, although a maximum of olivine [010] axes subperpendicular to the foliation is present in all samples with a few exceptions (Samples 153-920D-20R-1, Piece 13A, and 21R-1, Piece 12). Absence of obliquity between the lattice fabric and the spinel foliation is the rule.

Samples showing a complete transformation of coarse grains into a medium-grained mosaic (Pl. 1, Fig. 6 ) are rather common $(\approx 25 \%$ of the studied samples). The medium-grained olivine crystals commonly grow at the expense of large orthopyroxene crystals, resulting in a corroded appearance of the latter (Pl. 1, Fig. 7). Grain-size reduction into medium-grained mosaics is locally observed in orthopyroxene, although less commonly than in olivine (Pl. 1, Fig. 8). Clinopyroxene is commonly associated with orthopyroxene in these mosaics. Clinopyroxene also occurs as unstrained poikilitic grains enclosing medium-grained olivine crystals (Pl. 1, Fig. 9), which is interpreted as evidence for melt percolation occurring simultaneously with grainsize reduction (Cannat, Chatin, et al., this volume).

About $30 \%$ of these samples have a fine-grained olivine matrix. In these samples, the olivine grain-size distribution is bimodal (medium and fine grains) or trimodal (coarse, medium, and fine grains). These porphyroclastic textures (sensu stricto) are restricted to the up- 
A
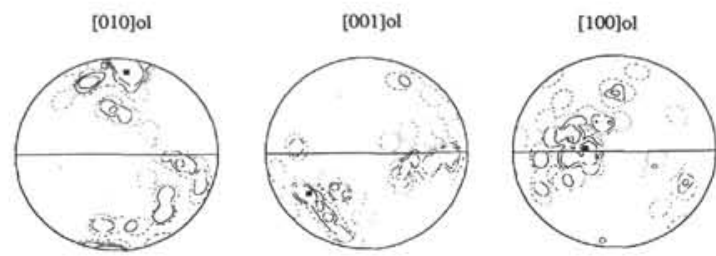

153-920D-10R-2, 48-52 (piece 6)

40
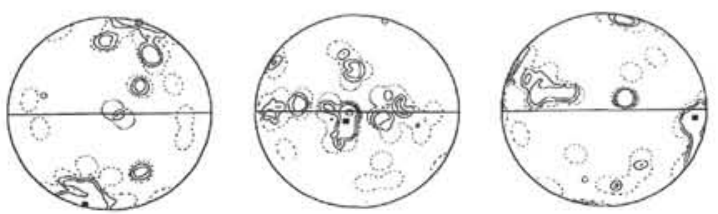

153-920D-12R-3, 82-86 (piece 4)
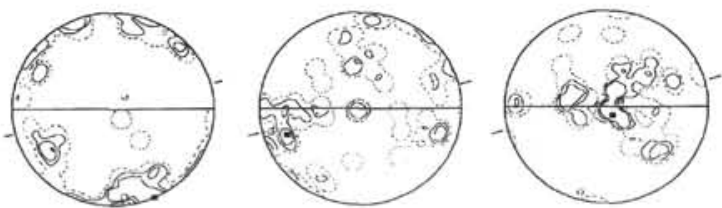

153-920D-15R-3, 48-54 (piece 3a)

so
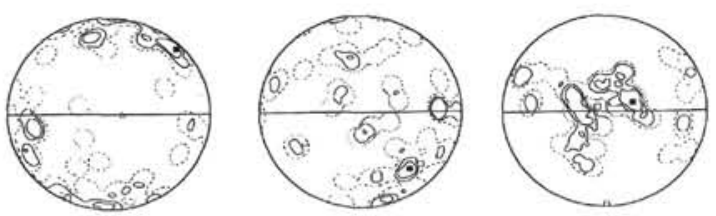

153-920D-15R-4, 108-113 (piece 3c)

46
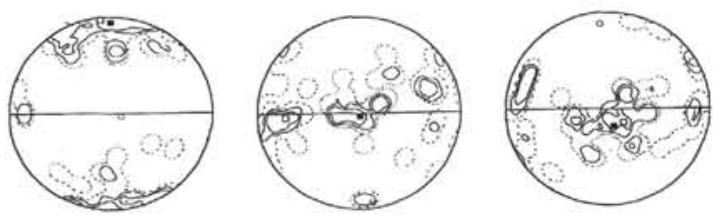

153-920D-15R-4, 79-86 (piece 3b)

50
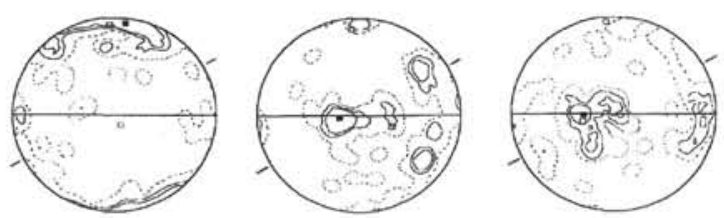

153-920D-16R-2, 9-15 (piece 1a)
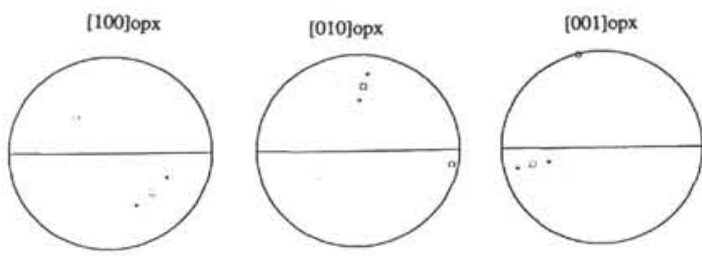

153-920D-10R-2, 48-52 (piece 6)
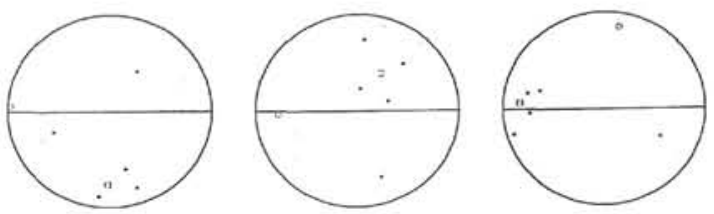

153-920D-12R-3, 82-86 (piece 4)
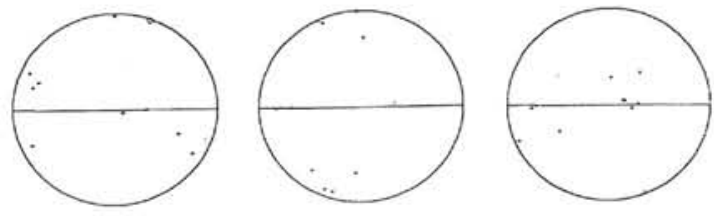

153-920D-1SR-4, 108-113 (piece 3c)
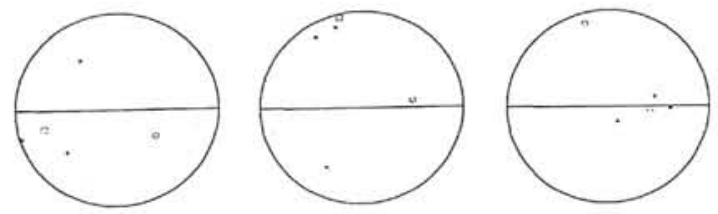

153-920D-15R-4, 79-86 (piece 3b)

3
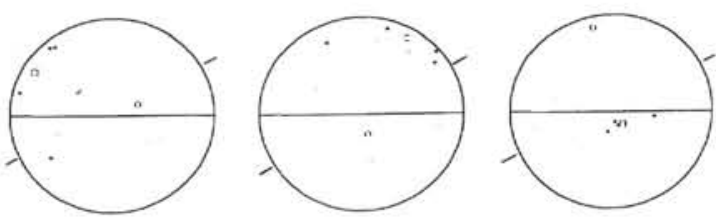

153-920D-16R-2, 9-15 (piece la)

Figure 4. Preferred lattice orientation of olivine and orthopyroxene in Hole 920D peridotites. Equal-area lower hemisphere projection. Contours at $1 \%, 3 \%$, and $5 \%$ per $1 \%$ area. Number of measurements given in italics beneath each sample number. East-west line $=$ trace of the horizontal plane. Tick marks $=$ trace of the foliation plane (spinel elongation in thin section). Open square = mean axis. Solid square = maximum axis. A. Coarse- and medium-grained textures. B. Mylonitic textures. 


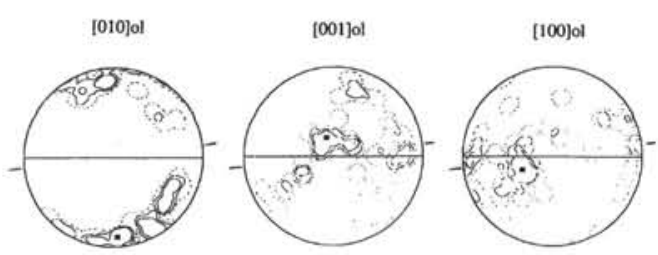

[100]opx

[010]opx

[001] opx

153-920D-16R-4, 29-35 (piece 1a)

40

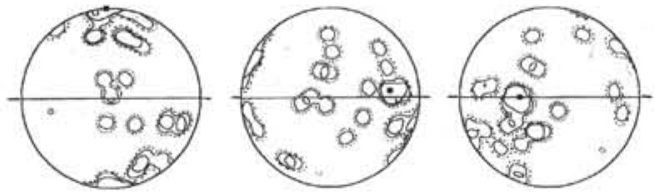

153-920D-17R-2, 80-86 (piece 10)

30

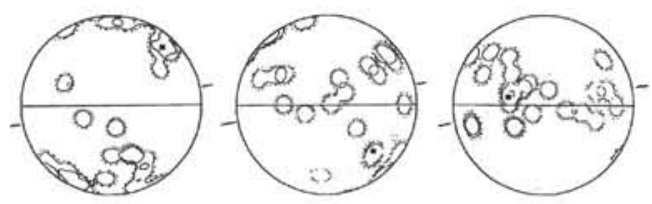

153-920D-20R-1, 87-93 (piece 13a)

23

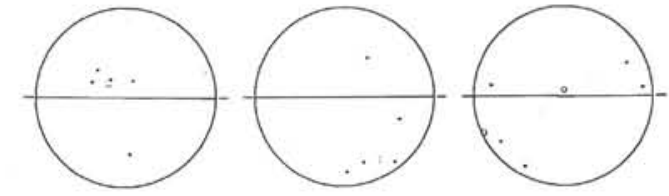

153-920D-17R-2, 80-86 (piece 10)

5

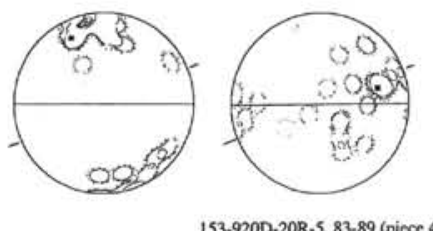

153-920D-20R-5, $83-89$ (piece 4)

21
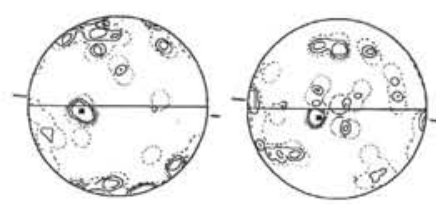

153-920D-21R-1, 84-90 (piece 12)
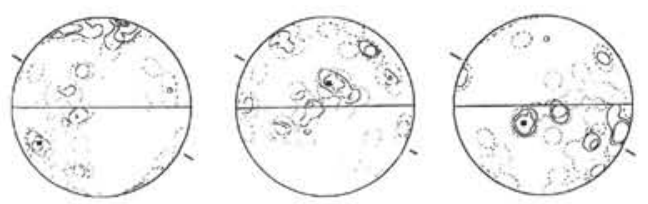

153-920D-21R-3, 110-116 (piece 8)
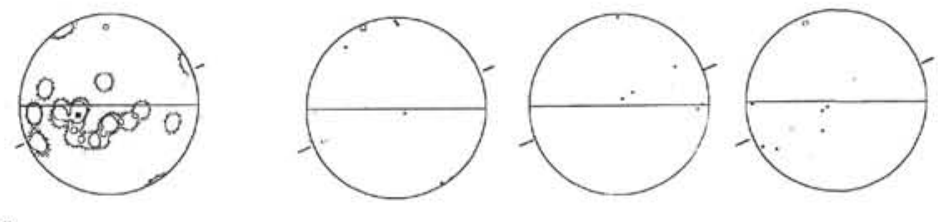

153-920D-20R-5, 83-89 (piece 4)

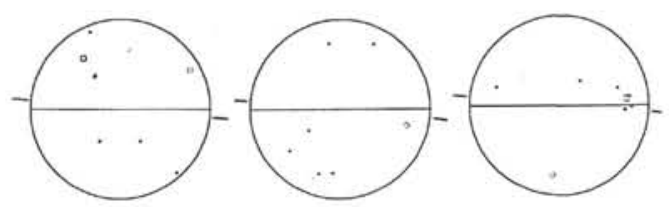

153-920D-2IR-1, 84-90 (piece 12)

Figure 4 (continued), 


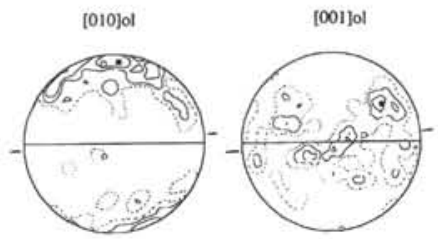

153-920D-22R-2, 43-50 (piece Ib)

97
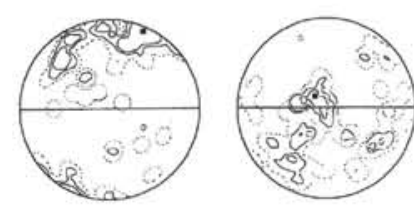

153-920D-22R-3, 12-16 (piece la)

66
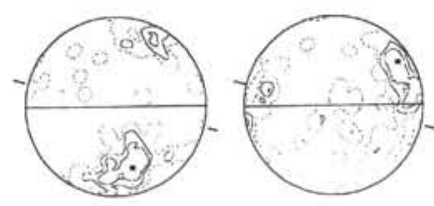

153-920D-22R-3, 32-37 (piece la)

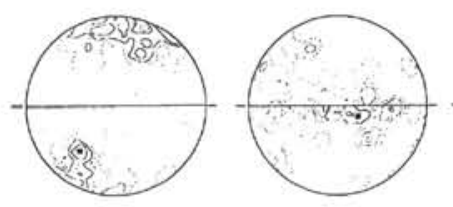

153-920D-22R-4, 64-70 (piece Ic)

60
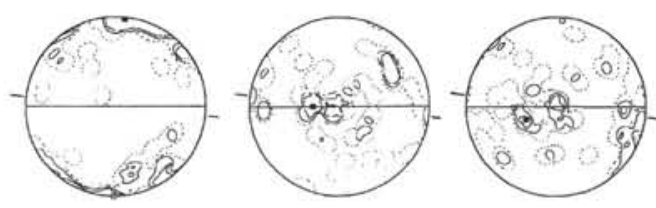

153-920D-22R-7, $77-84$ (piece 5)

so
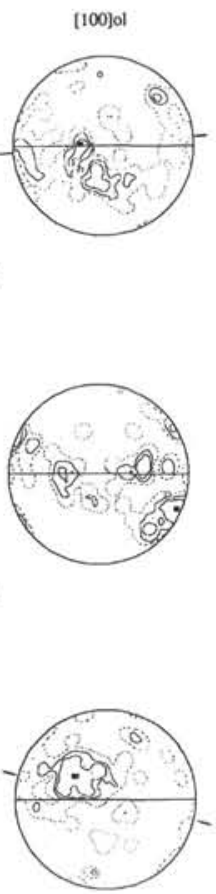

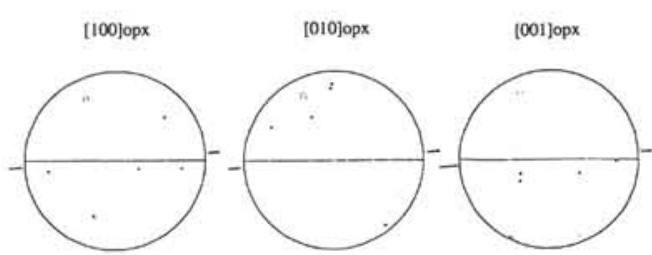

153-920D-22R-2, 43-50 (piece 1b)
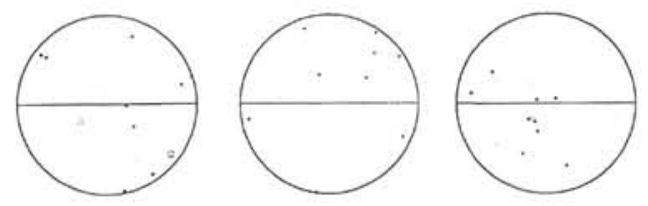

153-920D-22R-3, $12-16$ (piece la)

9

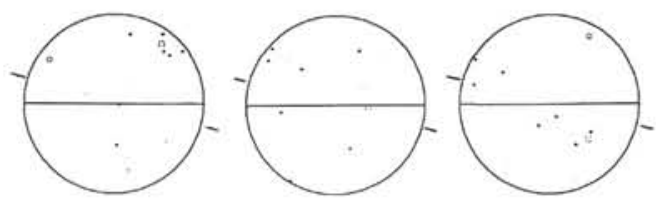

153-920D-22R-3, 32-37 (piece 1a)

7

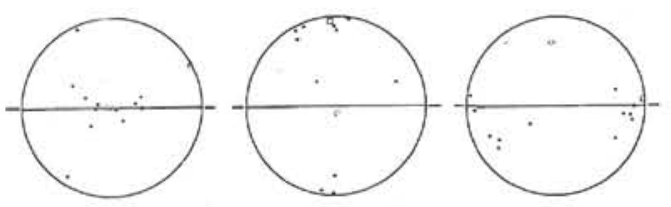

153-920D-22R-4, $64-70$ (piece 1c)

Figure 4 (continued).

per half of Hole 920D. Fine grains develop along grain and subgrain boundaries of medium and coarse grains (Pl. 1, Fig. 10). The finegrained matrix is generally not abundant, typically $10 \%-20 \%$ of the thin-section surface; it consists of a mosaic of equigranular, generally strain-free olivine and pyroxene grains, having well-developed $120^{\circ}$ triple junctions (Pl. 1, Fig. 12). Mylonites, characterized by an extreme development of the fine-grained matrix $(>90 \%)$ and evidence of distortion of orthopyroxene grain lattices (Pl. 1, Fig. 11), are uncommon $(<1 \%$ of Hole $920 \mathrm{D})$, and, in all cases, are associated with gabbroic veins (Cannat, Chatin, et al., this volume). Preferred orientations of olivine lattices in mylonites are stronger than in coarse- to medium-grained textures (Fig. 4B). The girdles defined by the [010] and [001] crystallographic axes indicate the activation of relatively low-temperature glide systems of dislocations in olivine (Boullier and Nicolas, 1973; Nicolas and Poirier, 1976; Mercier, 1985).

\section{ORIENTATION OF CRYSTAL-PLASTIC STRUCTURES}

Preferred orientation of orthopyroxene shape is the only mesoscopic textural element from which orientation of crystal-plastic flow structures were measured systematically on board. The foliation plane related to the crystal-plastic fabric was defined as the preferred flattening plane of orthopyroxene. Shipboard measurements established that this planar structure dips gently to moderately throughout 
B

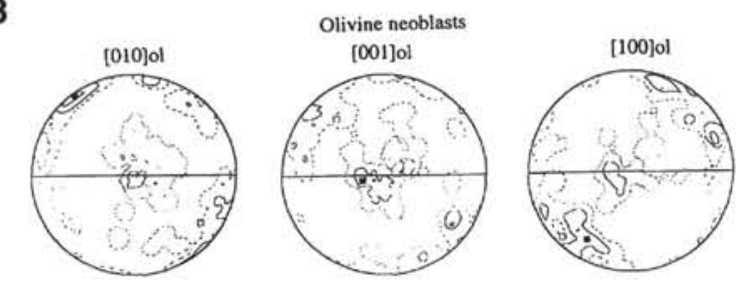

153-920D-2R-1, 126-132 (piece 13a)

100

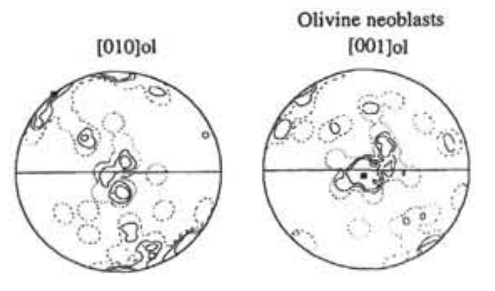

153-920D-2R-2, 39-47 (piece 7b)

45

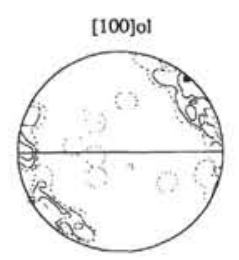

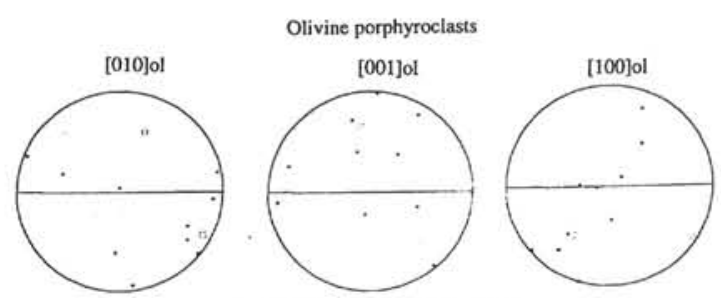

153-920D-2R-1, 126-132 (piece 13a)

10
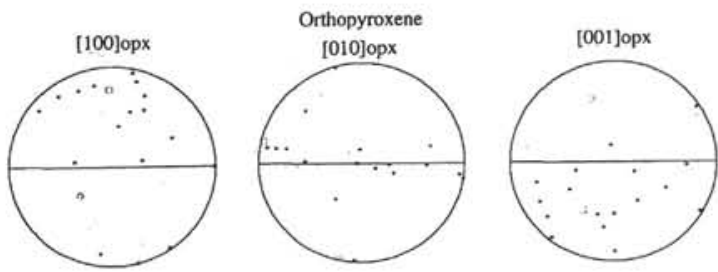

153-920D-2R-1, 126-132 (piece 13a)

17

Figure 4 (continued).

Hole $920 \mathrm{D}$; dips range from $15^{\circ}$ to $55^{\circ}$, and average about $30^{\circ}$ (Fig. 5). In about $70 \%$ of the thin sections studied, spinel grains appear to have a shape fabric that defines a foliation plane. Spinels are prismatic or holly-leaf shaped in the remaining $30 \%$. The dip of the spinel foliation ranges from $0^{\circ}$ to $40^{\circ}$ (Fig. 5), and averages $11^{\circ}$ (mean of 52 thin-section measurements distributed throughout Hole 920D). The olivine [010] and pyroxene [100] crystallographic axes systematically show a peak in their distributions perpendicular to the trace of the spinel foliation (Fig. 4A). This nice consistency between the spinel foliation and the olivine and pyroxene lattice fabrics, and the marked obliquity between the spinel and pyroxene foliations, seem to indicate that the foliation planes measured on board were mostly artifacts resulting from the fragmentation of orthopyroxenes by the anastomosing network of serpentine veins. As a consequence, the average foliation plane related to the crystal-plastic deformation in Hole $920 \mathrm{D}$ dips less than was suspected on board on the basis of mesoscopic observations of orthopyroxene (Fig. 5). No clear downhole evolution of the foliation dip is observed from Hole 920D (Fig. 5). The systematic absence of any significant obliquity between the spinel elongation and the trace of the preferred olivine (010) crystallographic plane suggest that simple shear was not the dominant deformation mechanism of Hole 920D peridotites (Nicolas and Poirier, 1976).

Orientations of core samples, determined from paleomagnetic measurements, show that the foliation plane (spinel elongation and lattice fabric) has an average north-south strike, parallel to the MidAtlantic Ridge axis, and an average dip of $11^{\circ}$. The foliation plane deduced from the spinel shape fabric (Fig 4A) apparently tends to evolve from an eastward dip down to Section 153-920D-20R-5 to a moderate westward dip in the lowermost part of Hole 920D, although this conclusion needs to be confirmed by further studies.

No preferred elongation of pyroxene or spinel crystals was found mesoscopically on faces cut parallel to the foliation plane. However, the preferred orientations of olivine [100] and orthopyroxene [001] crystallographic axes indicate the existence of a preferred flow direction associated with the crystal-plastic deformation, although there is no obvious mesoscopic lineation. Absolute orientation of these crystallographic axes cluster in the east-west to northwest-southeast sector (Table 1; Fig. 6).

\section{SUMMARY AND CONCLUSION}

The range of textures exhibited by Site 920 peridotites reflects an evolution of the temperature and stress conditions during plastic deformation of this segment of the oceanic mantle. Three "stages" in the high-temperature, tectonic evolution of these peridotites can be schematically distinguished. The earliest is characterized by the development of a coarse-grained equigranular texture, and a moderately developed shape and lattice preferred orientation. The lattice fabrics are diagnostic of a crystal-plastic flow mechanism by dislocation glide with activation of the high-temperature slip systems of olivine and orthopyroxene (around $1200^{\circ} \mathrm{C}$; Carter and Avé Lallemant, 1970; Nicolas and Poirier, 1976; Darot and Gueguen, 1980; Kirby, 1983; Mercier, 1985). The coarse recrystallized grain size of olivine and the recovered substructure are also indicative of high-temperature, lowstress (< $1 \mathrm{MPa}$; Karato, 1984) conditions of deformation considered to be typical of an asthenospheric setting. Accordingly, the orientation of the shape and lattice fabrics associated with this texture indicates that the asthenospheric flow plane was subhorizontal (about $10^{\circ}$ dip), and that the asthenospheric flow direction was oriented at a high angle to the spreading-ridge axis when the mantle was incorporated into the lithosphere, assuming that no major rotation occurred before serpentinization (i.e., before the acquisition of the magnetic signature from which all our structural data are reoriented). Similar coarsegrained textures and moderately developed lattice fabrics with poorly defined obliquities with the foliation planes are characteristic of peridotites cropping out in mantle diapirs frozen beneath paleo-spreading centers in ophiolites, and contrast strongly with the very highly strained ophiolitic peridotites cropping out away from the zones of diapiric flow (Ceuleneer, 1991).

The coarse-grained equigranular texture is fully preserved in only about $5 \%$ of the samples; it becomes more abundant downhole. The acquisition of the lattice preferred orientation associated with the coarse-grained texture was followed ("second stage" of crystal-plastic deformation) by an episode of extensive grain-size reduction: 70\% of the samples studied show incipient development of mediumgrained olivine and, less commonly, pyroxene mosaics at the expense of coarse grains of both olivine and orthopyroxene. In about $25 \%$ of the samples, the medium-grained matrix has totally replaced the pre- 
Dip pyrox. foliation (deg.)
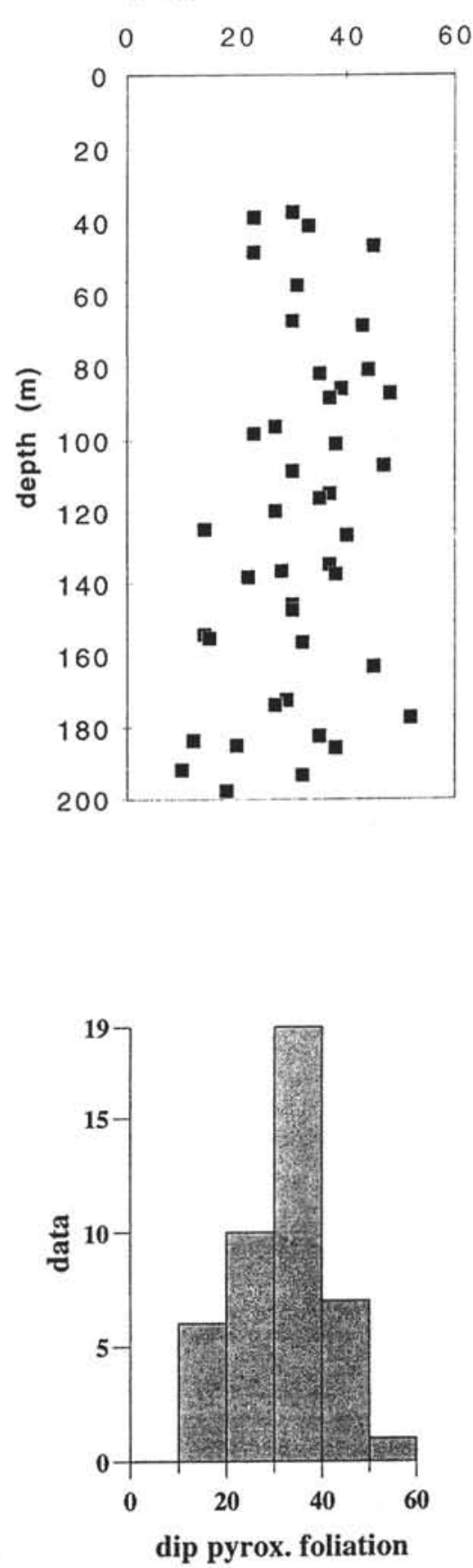

Dip spinel foliation (deg.)
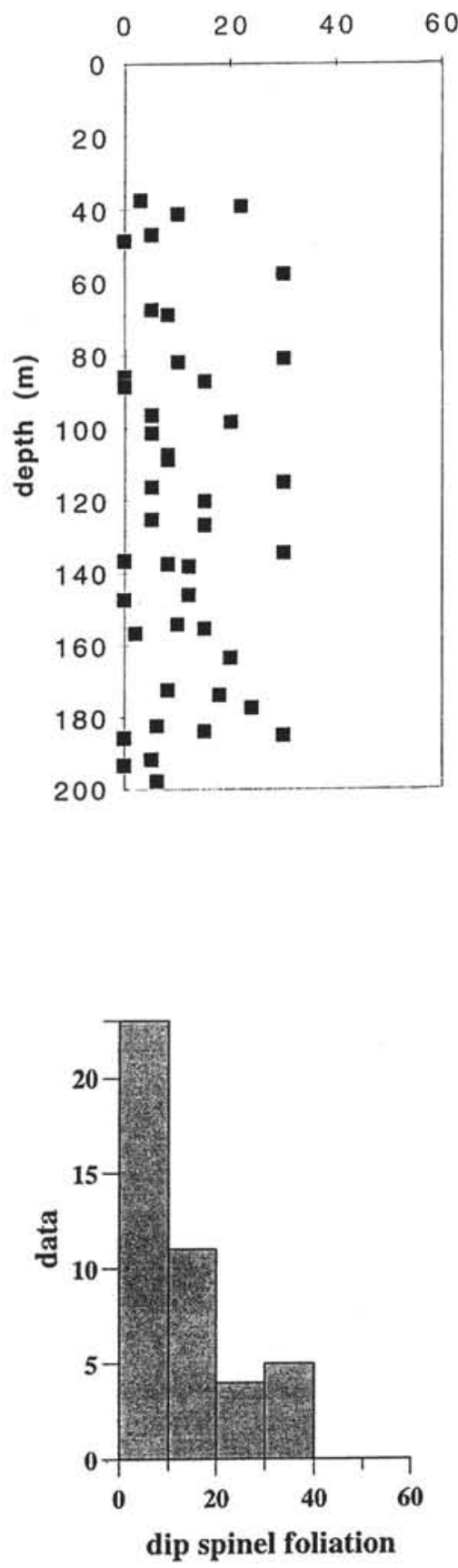

Figure 5. Comparison between foliation dip defined on the basis of pyroxene (pyrox.) shape fabric (mesoscopic observation) and spinel shape fabric (microscopic observation); deg. $=$ degrees. Pyroxene foliations are shown only for pieces whose spinel foliations were measured in thin section. vious coarse-grained texture. Olivine crystals of this new generation commonly display well-developed euhedral shapes, but no shape nor lattice preferred orientation. This is interpreted as an important episode of quasi-static recrystallization at high temperature that postdated high-temperature plastic flow (i.e., which followed the incorporation of the asthenosphere into the lithosphere). Evidence for melt percolation occurring simultaneously with this recrystallization event is discussed in Cannat, Chatin, et al. (this volume).

The "third stage" of crystal-plastic deformation of Hole 920D peridotites corresponds to the relatively rare development of a finegrained $(0.1-0.03 \mathrm{~mm})$ matrix, and of closely spaced subgrain boundaries in olivine and pyroxene (i.e., the formation of a porphyroclastic texture) (Mercier and Nicolas, 1975). This is interpreted as a deformation overprint that developed at relatively high stress (10-
$100 \mathrm{MPa}$; Karato, 1984) and low temperature (around $1000^{\circ} \mathrm{C}$ ), in lithospheric conditions. We observed a clear downhole decrease of this late, high-stress overprint, which is virtually restricted to the upper half of Hole 920D. Such a textural evolution is commonly observed in ophiolitic peridotites near mylonitic shear zones (Boudier et al., 1988). The presence of a major lithospheric shear zone above the present outcrop surface of Site 920 peridotites may thus be proposed. True mylonites ( $>90 \%$ fine-grained matrix) are particularly rare $(<1 \%$ of the cumulate recovery), and are restricted to millimeterto centimeter-thick shear zones that are, in all cases, spatially related to gabbroic veins (Cannat, Chatin, et al., this volume).

These data show that crystal-plastic deformation in Site 920 mantle peridotites ceased after a moderate amount of flow along a subhorizontal flow plane, and a flow direction oriented at a high angle to 
Table 1. Azimuth of the lineation associated with the crystal-plastic fabric in Hole 920D, deduced from olivine [100] and orthopyroxene [001] preferred orientations.

\begin{tabular}{|c|c|c|c|}
\hline Sample & $\begin{array}{l}\text { Mean olivine } \\
{[100] \text { axis }}\end{array}$ & $\begin{array}{c}\text { Maximum olivine } \\
{[100] \text { axis }}\end{array}$ & $\begin{array}{c}\text { Mean orthopyroxene } \\
{[001] \text { axis }}\end{array}$ \\
\hline \multicolumn{4}{|l|}{ 153-920D- } \\
\hline $2 \mathrm{R}-1,126-132 \mathrm{~cm}$ (Piece 13A) & $\mathrm{N} 116^{\circ} \mathrm{E}$ & $\mathrm{N} 141^{\circ} \mathrm{E}$ & \\
\hline $10 \mathrm{R}-2,48-52 \mathrm{~cm}$ (Piece 6) & $\mathrm{N} 120^{\circ} \mathrm{E}$ & $\mathrm{N} 134^{\circ} \mathrm{E}$ & $\mathrm{N} 100^{\circ} \mathrm{E}$ \\
\hline $12 \mathrm{R}-3,82-86 \mathrm{~cm}$ (Piece 4) & $\mathrm{N} 108^{\circ} \mathrm{E}$ & $\mathrm{N} 126^{\circ} \mathrm{E}$ & $\mathrm{N} 094^{\circ} \mathrm{E}$ \\
\hline $15 \mathrm{R}-3,48-54 \mathrm{~cm}$ (Piece 3A) & $\mathrm{N} 103^{\circ} \mathrm{E}$ & $\mathrm{N} 098^{\circ} \mathrm{E}$ & \\
\hline $15 \mathrm{R}-4,79-86 \mathrm{~cm}$ (Piece 3B) & $\mathrm{N} 160^{\circ} \mathrm{E}$ & $\mathrm{N} 151^{\circ} \mathrm{E}$ & $\mathrm{N} 003^{\circ} \mathrm{E}$ \\
\hline $15 \mathrm{R}-4,108-113 \mathrm{~cm}$ (Piece 3C) & $\mathrm{N} 147^{\circ} \mathrm{E}$ & $\mathrm{N} 177^{\circ} \mathrm{E}$ & \\
\hline 16R-2, 9-15 cm (Piece 1A) & $\mathrm{N} 144^{\circ} \mathrm{E}$ & $\mathrm{N} 146^{\circ} \mathrm{E}$ & $\mathrm{N} 179^{\circ} \mathrm{E}$ \\
\hline 16R-4, 29-35 cm (Piece 1A) & $\mathrm{N} 151^{\circ} \mathrm{E}$ & $\mathrm{N} 140^{\circ} \mathrm{E}$ & \\
\hline $20 \mathrm{R}-1,87-93 \mathrm{~cm}$ (Piece 13Á) & $\mathrm{N} 133^{\circ} \mathrm{E}$ & $\mathrm{N} 130^{\circ} \mathrm{E}$ & \\
\hline $20 \mathrm{R}-5,83-89 \mathrm{~cm}$ (Piece 4$)$ & $\mathrm{N} 061^{\circ} \mathrm{E}$ & $\mathrm{N} 041^{\circ} \mathrm{E}$ & $\mathrm{N} 049^{\circ} \mathrm{E}$ \\
\hline $21 \mathrm{R}-1,84-90 \mathrm{~cm}$ (Piece 12) & $\mathrm{N} 003^{\circ} \mathrm{E}$ & $\mathrm{N} 014^{\circ} \mathrm{E}$ & $\mathrm{N} 037^{\circ} \mathrm{E}$ \\
\hline $22 \mathrm{R}-2,43-50 \mathrm{~cm}$ (Piece IB) & $\mathrm{N} 090^{\circ} \mathrm{E}$ & $\mathrm{N} 092^{\circ} \mathrm{E}$ & $\mathrm{N} 096^{\circ} \mathrm{E}$ \\
\hline $22 \mathrm{R}-3,12-16 \mathrm{~cm}$ (Piece 1A) & $\mathrm{N} 100^{\circ} \mathrm{E}$ & $\mathrm{N} 080^{\circ} \mathrm{E}$ & $\mathrm{N} 130^{\circ} \mathrm{E}$ \\
\hline $22 \mathrm{R}-3,32-37 \mathrm{~cm}$ (Piece 1A) & $\mathrm{N} 154^{\circ} \mathrm{E}$ & $\mathrm{N} 156^{\circ} \mathrm{E}$ & \\
\hline $22 \mathrm{R}-4,64-70 \mathrm{~cm}$ (Piece 1C) & $\mathrm{N} 080^{\circ} \mathrm{E}$ & $\mathrm{N} 044^{\circ} \mathrm{E}$ & $\mathrm{N} 100^{\circ} \mathrm{E}$ \\
\hline
\end{tabular}

Notes: These values have been obtained after rotation of the petrofabric data (Fig. 4) around a vertical axis. Rotation angle depends on the thin-section orientation and on the magnetic declination (Hurst et al., this volume).

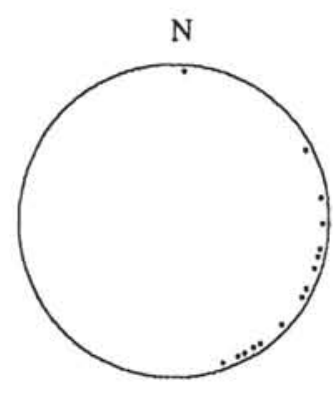

[100]ol - average

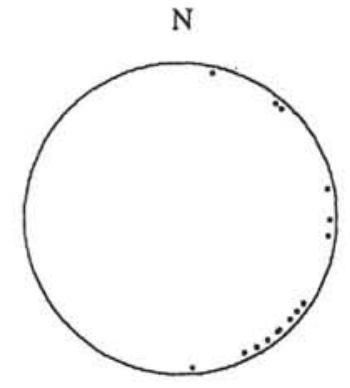

[100]ol- maximum

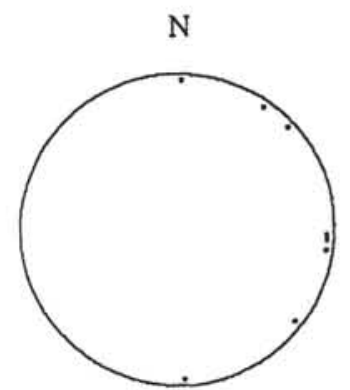

[001] $]$ px - average
Figure 6. Preferred azimuth of olivine (ol) [100] axes (average and maximum) and of orthopyroxene (opx) [001] axes reoriented using onboard paleomagnetic measurements (Hurst et al., this volume). the Mid-Atlantic Ridge axis. Following incorporation into the lithosphere, the mantle temperature decreased sufficiently slowly to allow extensive static recrystallization of olivine and, to a lesser extent, orthopyroxene, contemporary with basaltic melt percolation. Overprint of mylonitic deformation is very restricted and is essentially focused into discrete zones of evolved melt injection. A few sheared serpentinites have been recovered at Site 920 , and are evidence for late fault zones crosscutting the peridotites. It is perhaps likely that the low abundance of this low-temperature deformation facies in the recovered part of Holes 920B and 920D is an artifact of the drilling itself. It remains that the final emplacement process of serpentinized peridotites at seafloor level along this segment of the Mid-Atlantic Ridge has left intact a 200-m-thick pile of structurally coherent mantle rocks.

\section{ACKNOWLEDGMENTS}

We are indebted to the ODP staff and to the officers and crew of the JOIDES Resolution on board during Leg 153. We thank J. Karson, H. Avé Lallemant, and J. Ross for constructive reviews of this paper.

\section{REFERENCES}

Boudier, F., Ceuleneer, G., and Nicolas, A., 1988. Shear zones, thrusts, and related magmatism in the Oman ophiolite: initiation of thrusting on an oceanic ridge. Tectonophysics, 151:275-296.
Boullier, A.-M., and Nicolas, A., 1973. Texture and fabric of peridotite nodules from kimberlites at Mothae, Thaba Putosa and Kimberley. In Nixon, P.H. (Ed.), Lesotho Kimberlites: Lesotho National Dev. Corp., 57-66.

Cannat, M., 1993. Emplacement of mantle rocks in the seafloor at mid-ocean ridges. J. Geophys. Res., 98:4163-4172.

Cannat, M., Bideau, D., and Hébert, R., 1990a. Plastic deformation and magmatic impregnation in serpentinized ultramafic rocks from the Garrett transform fault (East Pacific Rise). Earth Planet. Sci. Lett., 101:216-232.

Cannat, M., and Casey, J.F., 1995. An ultramafic lift at the Mid-Atlantic Ridge: successive stages of magmatism in serpentinized peridotites from the $15^{\circ} \mathrm{N}$ region. In Vissers, R.L.M., and Nicolas, A. (Eds.), Mantle and Lower Crust Exposed in Oceanic Ridges and Ophiolites: Dordrecht (Kluwer), 5-34.

Cannat, M., Juteau, T., and Berger, E., 1990b. Petrostructural analysis of the Leg 109 serpentinized peridotites. In Detrick, R., Honnorez, J., Bryan, W.B., Juteau, T., et al., Proc. ODP, Sci. Results, 106/109: College Station, TX (Ocean Drilling Program), 47-57.

Cannat, M., Karson, J.A., Miller, D.J., et al., 1995. Proc. ODP, Init. Repts., 153: College Station, TX (Ocean Drilling Program).

Cannat, M., Mével, C., Maia, M., Deplus, C., Durand, C., Gente, P., Agrinier, P., Belarouchi, A., Dubuisson, G., et al., 1995. Thin crust, ultramafic exposures, and rugged faulting patterns at the Mid-Atlantic Ridge $\left(22^{\circ}-\right.$ $\left.24^{\circ} \mathrm{N}\right)$. Geology, 23:49-52.

Carter, N.L., and Avé Lallemant, H.G., 1970. High-temperature flow of dunite and peridotite. Geol. Soc. Am. Bull., 81:2181-2202.

Ceuleneer, G., 1991. Evidences for a paleo-spreading center in the Oman ophiolite: mantle structures in the Maqsad area. In Peters, T., Nicolas, A., and Coleman, R.G. (Eds.), Ophiolite Genesis and Evolution of Oceanic Lithosphere: Dordrecht (Kluwer), 147-173.

Darot, M., and Gueguen, Y., 1981. High-temperature creep of forsterite single crystals. J. Geophys. Res., 86:6219-6234. 
Dick, H.J.B., 1989. Abyssal peridotites, very slow spreading ridges and ocean ridge magmatism. In Saunders, A.D., and Norry, M.J. (Eds.), Magmatism in the Ocean Basins. Geol. Soc. Spec. Publ. London, 42:71-105.

Girardeau, J., and Francheteau, J., 1993. Plagioclase-wehrlites and peridotites on the East Pacific Rise (Hess Deep) and the Mid-Atlantic Ridge (DSDP Site 339) evidence for magma percolation in the oceanic upper mantle. Earth Planet. Sci. Lett., 115:137-149.

Goetze, C., and Evans, B., 1979. Stress and temperature in the bending lithosphere as constrained by experimental rock mechanics. Geophys. J. R. Astron. Soc., 59:463-478.

Karato, S.I., 1984. Grain-size distribution and rheology of the upper mantle. Tectonophysics, 104:155-176.

Karson, J.A., 1990. Seafloor spreading on the Mid-Atlantic Ridge: implications for the structure of ophiolites and oceanic lithosphere produced in slow-spreading environments. In Malpas, J., Moores, E.M., Panayiotou, A., and Xenophontos, C. (Eds.), Ophiolites: Oceanic Crustal Analogues: Proc. Symp. "Troodos 1987": Nicosia, Cyprus (Minist. Agric. Nat. Resour.), 547-555.

Karson, J.A., Thompson, G., Humphris, S.E., Edmond, J.M., Bryan, W.B., Brown, J.R., Winters, A.T., Pockalny, R.A., Casey, J.F., Campbell, A.C., Klinkhammer, G., Palmer, M.R., Kinzler, R.J., and Sulanowska, M.M., 1987. Along-axis variations in seafloor spreading in the MARK area. Nature, 328:681-685.

Kirby, S.H., 1983. Rheology of the lithosphere. Rev. Geophys. Space Phys., 21:1458-1487.
Mercier, J.-C.C., 1985. Olivines and pyroxenes. In Wenk, H.R. (Ed.), Preferred Orientation in Deformed Metals and Rocks: An Introduction to Modern Texture Analyses: New York (Academic Press), 407-430.

Mercier, J.-C.C., and Nicolas, A., 1975. Textures and fabrics of upper mantle peridotites as illustrated by xenoliths from basalts. J. Petrol., 16:454 496.

Mével, C., Cannat, M., Gente, P., Marion, E., Auzende, J.-M., and Karson, J.A., 1991. Emplacement of deep crustal and mantle rocks on the west median valley wall of the MARK area (MAR $23^{\circ} \mathrm{N}$ ). Tectonophysics, 190:31-53.

Nicolas, A., Boudier, F., and Bouchez, J.-L., 1980. Interpretation of peridotite structures from ophiolite and oceanic environments. Am. J. Sci., 280:192-210.

Nicolas, A., and Poirier, J.-P., 1976. Crystalline Plasticity and Solid State Flow in Metamorphic Rocks: New York (Wiley).

Poirier, J.-P., 1985. Creep of Crystals: Cambridge (Cambridge Univ. Press).

Shipboard Scientific Party, 1979. Site $395: 23^{\circ} \mathrm{N}$, Mid-Atlantic Ridge. In Melson, W.G., Rabinowitz, P.D., et al., Init. Repts. DSDP, 45: Washington (U.S. Govt. Printing Office), 131-264.

Date of initial receipt: 7 August 1995

Date of acceptance: 25 April 1996

Ms 153SR-002 

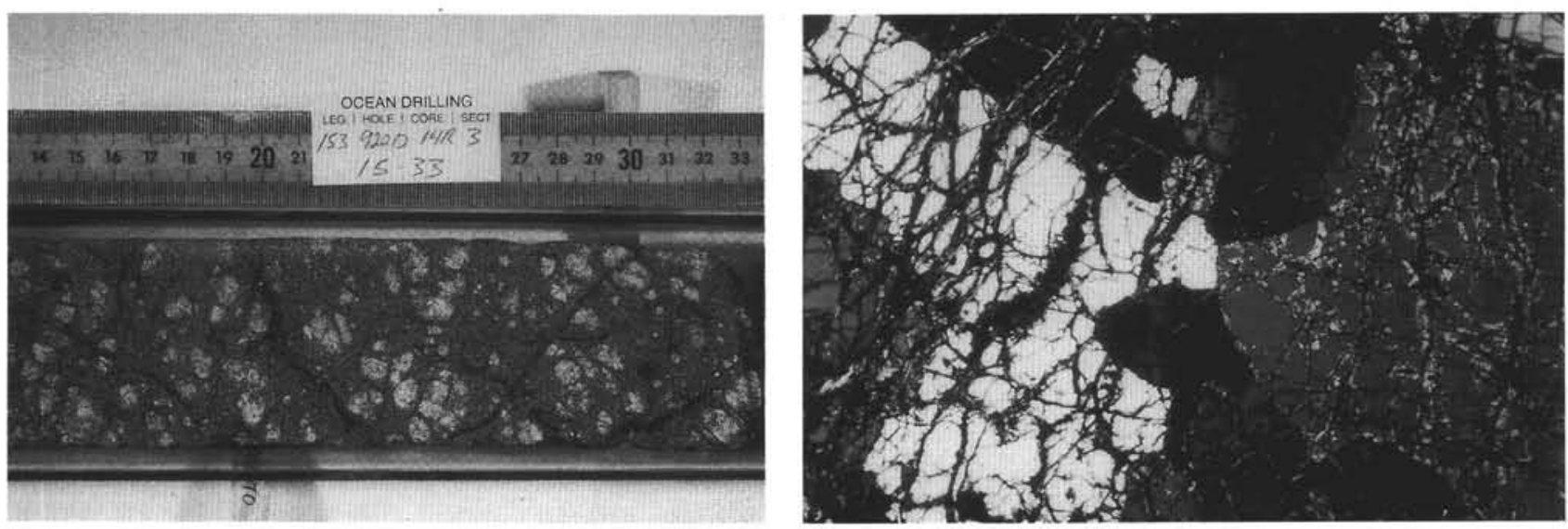

1

2
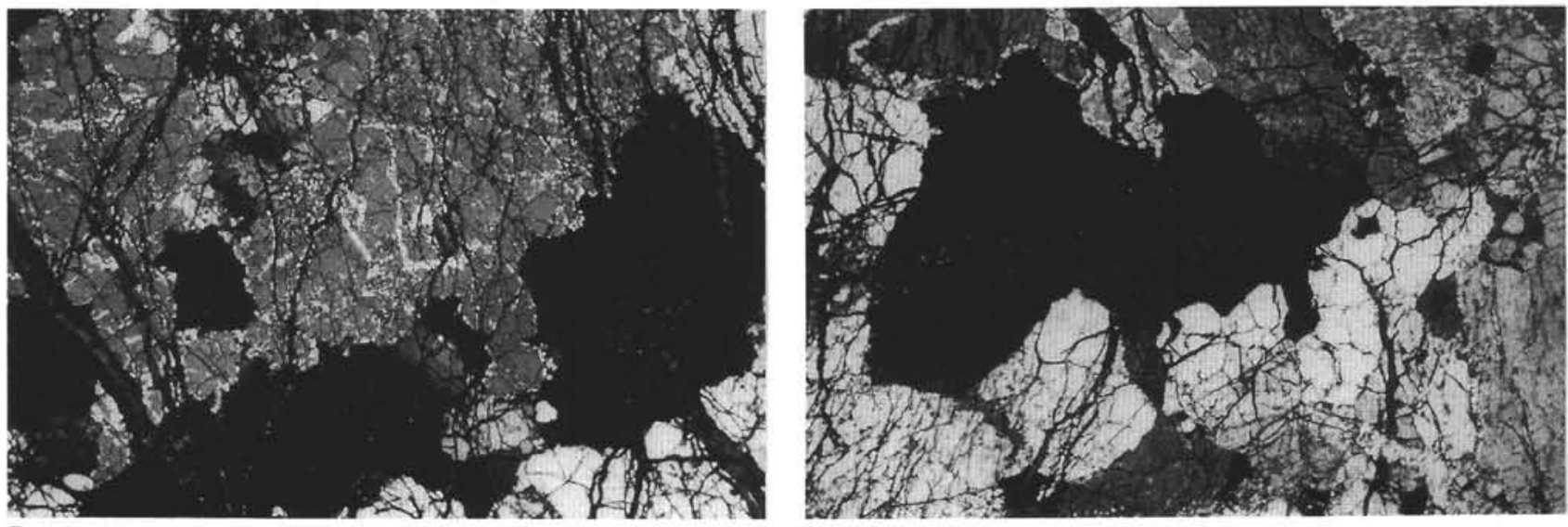

3

4
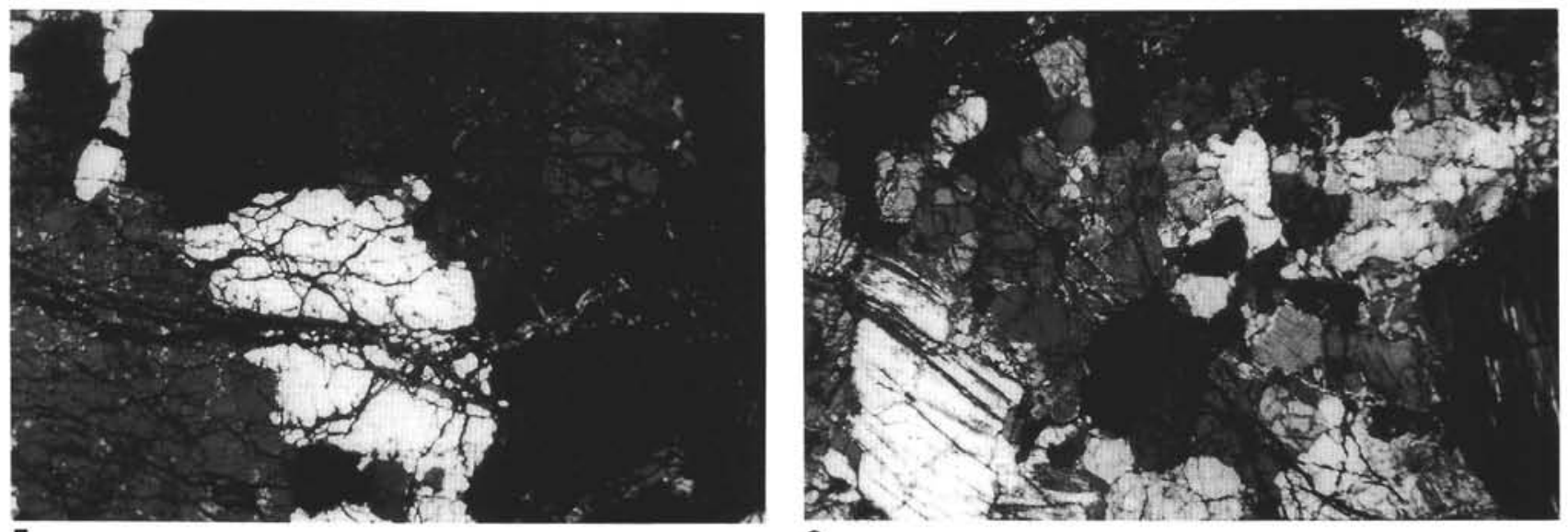

5

6

Plate 1. 1. Mesoscopic character of Site 920 serpentinized harzburgites. 2. Part of a very coarse $(>10 \mathrm{~mm})$ olivine grain. Relict coarse-grained texture. Length of the field is $6 \mathrm{~mm}$. Sample 153-920D-18R-1 (Piece 1). 3. Typical recrystallized texture in olivine. Note the $120^{\circ}$ triple junctions and the prismatic olivine crystals. Length of the field is $6 \mathrm{~mm}$. Sample 153-920D-16R-6 (Piece 10). 4. Development of a medium-grained texture by static recrystallization after a coarsegrained texture. Length of the field is $6 \mathrm{~mm}$. Sample 153-920D-18R-1 (Piece 5). 5. Growth of a strain-free, medium-grained olivine within a coarse olivine with a dense substructure. Length of the field is $6 \mathrm{~mm}$. Sample 153-920D-18R-1 (Piece 5). 6. Typical medium-grained olivine mosaic. Length of the field is $12 \mathrm{~mm}$. Sample 153-920D-18R-2 (Piece 13). 


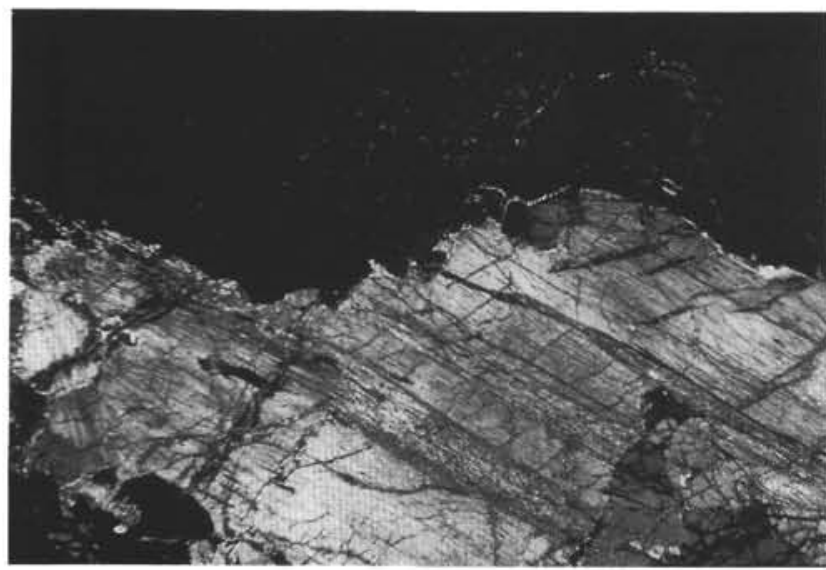

7

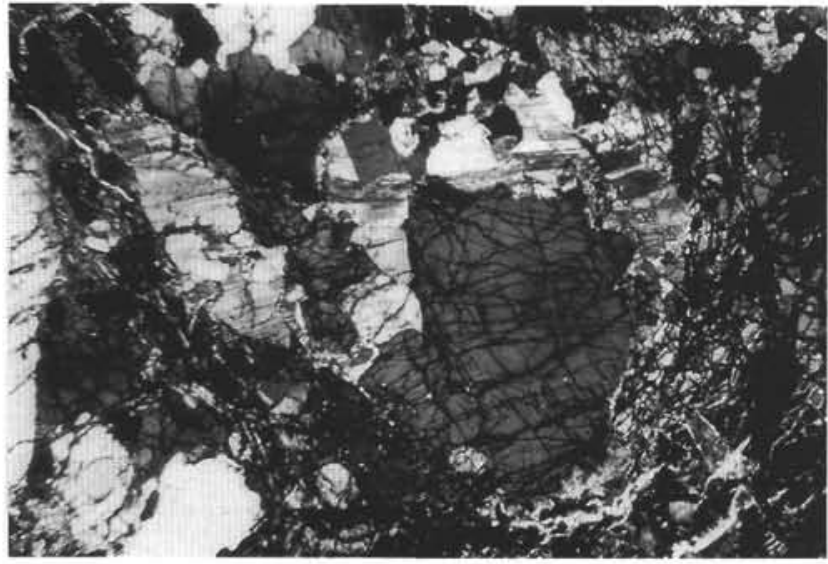

9

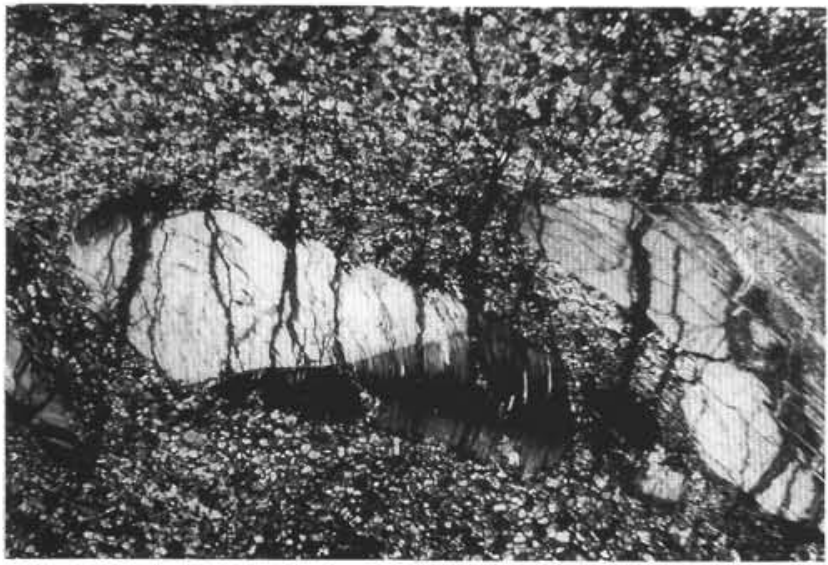

11

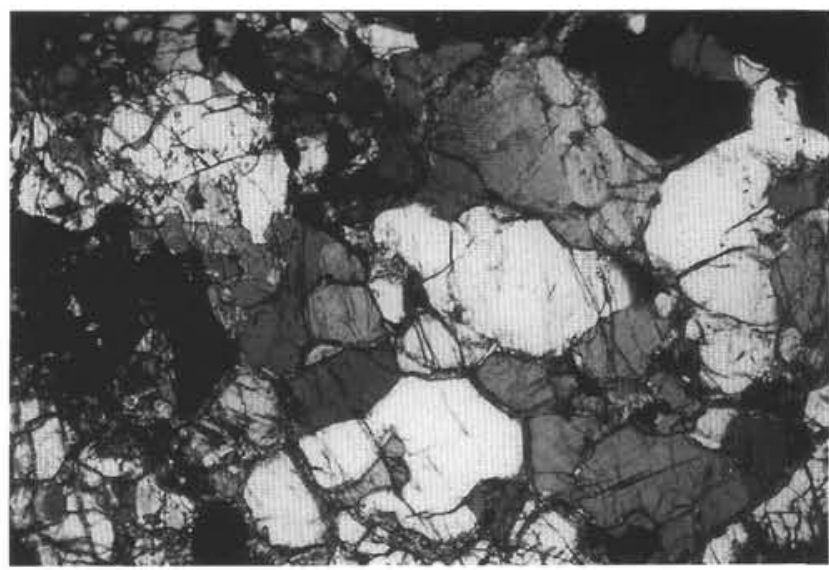

8

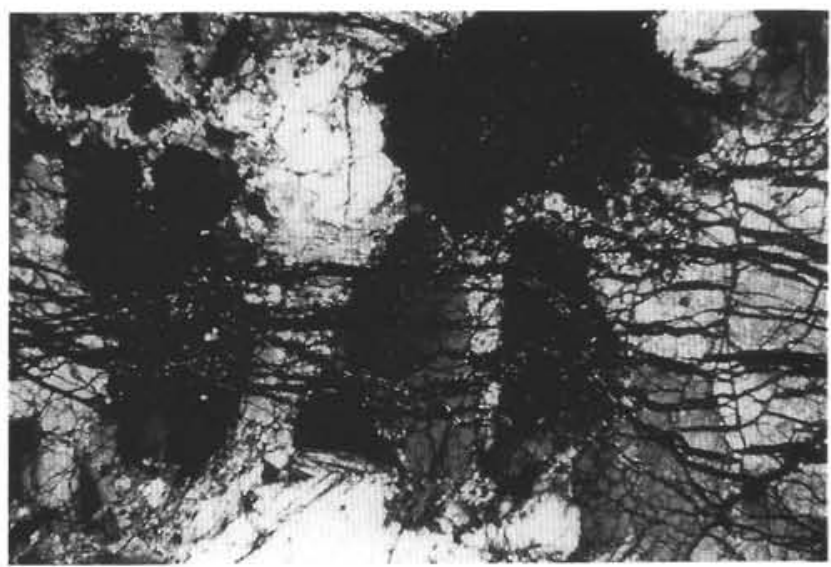

10

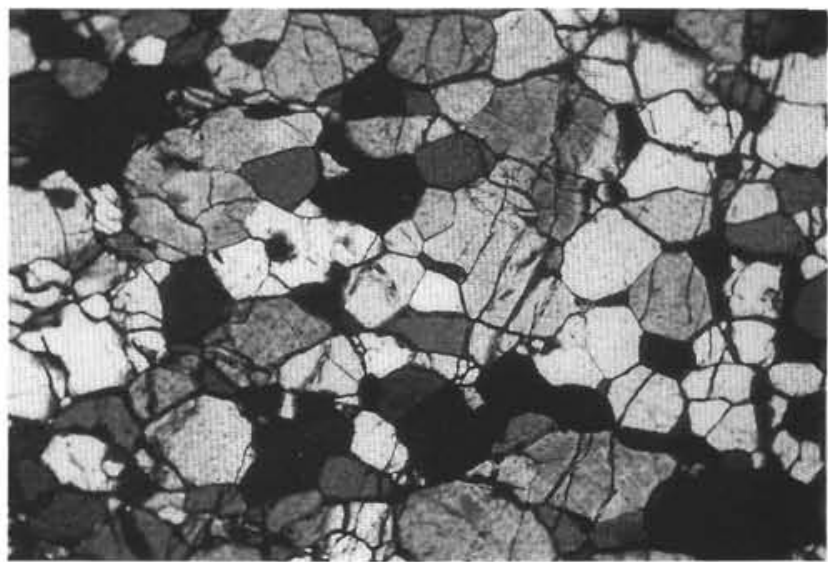

12

Plate 1 (continued). 7. Growth of medium-grained olivine within a coarse orthopyroxene porphyroclast, conferring a resorbed aspect to this porphyroclast. Length of the field is $10 \mathrm{~mm}$. Sample 153-920D-18R-1 (Piece 1). 8. Recrystallization of a coarse orthopyroxene porphyroclast into a medium-grained mosaic. Length of the field is $6 \mathrm{~mm}$. Sample 153-920D-15R-4 (Piece 1). 9. Poikilitic clinopyroxene crystals enclosing olivine and orthopyroxene. Length of the field is $8 \mathrm{~mm}$. Sample 153-920D-15R-4 (Piece 1). 10. Development of a fine-grained matrix along subgrain and grain boundaries of a coarse-grained olivine porphyroclast. Protomylonitic texture. Length of the field is $12 \mathrm{~mm}$. Sample 153-920D-13R-2 (Piece 7). 11. Orthopyroxene porphyroclast with undulose extinction in a fine-grained olivine and orthopyroxene matrix. Mylonitic texture. Length of the field is $8 \mathrm{~mm}$. Sample 153-920D-2R-1 (Piece 13B). 12. Fine-grained mosaic made of strain-free, equigranular, olivine crystals in a mylonite. Length of the field is $1.5 \mathrm{~mm}$. Sample 153-920D-2R-1 (Piece 13B). 